\title{
A study of the up-and-down method for non-normal distribution functions
}

\author{
Vibholm, Svend; Thyregod, Poul
}

Published in:

IEEE Transactions on Electrical Insulation

Link to article, DOI:

$10.1109 / 14.2375$

Publication date:

1988

Document Version

Publisher's PDF, also known as Version of record

Link back to DTU Orbit

Citation (APA):

Vibholm, S., \& Thyregod, P. (1988). A study of the up-and-down method for non-normal distribution functions. IEEE Transactions on Electrical Insulation, 23(3), 357-364. https://doi.org/10.1109/14.2375

\section{General rights}

Copyright and moral rights for the publications made accessible in the public portal are retained by the authors and/or other copyright owners and it is a condition of accessing publications that users recognise and abide by the legal requirements associated with these rights.

- Users may download and print one copy of any publication from the public portal for the purpose of private study or research.

- You may not further distribute the material or use it for any profit-making activity or commercial gain

- You may freely distribute the URL identifying the publication in the public portal

If you believe that this document breaches copyright please contact us providing details, and we will remove access to the work immediately and investigate your claim 


\title{
A Study of the Up-and-Down Method for non-Normal Distribution Functions
}

\author{
S. Vibholm and P. Thyregod \\ Physics Laboratory 2, IMSOR, Technical University \\ of Denmark, Lyngby, Denmark
}

\begin{abstract}
We discuss the assessment of breakdown probabilities by means of the up-and-down method. The exact maximum likelihood estimates for a number of response patterns are calculated for three different distribution functions and are compared with the estimates corresponding to the normal distribution. Estimates of the $50 \%$ probability breakdown voltage and of the scale parameter of the breakdown probability functions are investigated.
\end{abstract}

\section{INTRODUCTION}

$\mathrm{I}$

$\mathbf{N}$ order to design insulation systems it is necessary Ito assess the breakdown probability of the various insulation components of the system. The up-and-down method is widely used for estimation of the $50 \%$ probability breakdown voltage $U_{50}$. The analysis may be extended to include estimates of the scale parameter $\sigma$ in the breakdown probability function. There are doubts, however, as to what extent these estimates are influenced by the proper choice of the underlying breakdown distribution function [1-4]. The design of the up-anddown test ensures that the choice of the assumed distribution function has only a minor influence on the estimation of $U_{50}$. The choice of distribution can, however, strongly affect the prediction of lower fractiles.

In a previous paper [5] the authors have compared the Dixon and Mood approximation to the maximum likelihood estimate with the exact maximum likelihood estimate $[6,7]$ assuming a normal distribution for a number of response patterns. We concluded that, with digital computers readily available, a statistical analysis of a set of data obtained from an up-and-down test may just as well be performed directly from a maximum likelihood estimation, instead of applying the approximate method used by Dixon and Mood $[8,9]$.

In the present paper the maximum likelihood estimates of $U_{50}$ and $\sigma$ for a normal distribution of breakdown probabilities are compared with the maximum likelihood estimates of $U_{50}$ and $\sigma$ for the following distributions of breakdown probabilities: a double exponential distribution, a logistic distribution $[2,3]$, and a Weibull distribution with a shape parameter value of 5 , in the following given the notation Weibull-5. The Weibull-5 distribution is very similar to the modified Weibull distribution curve proposed by Carrara [1].

\section{MAXIMUM LIKELIHOOD ESTIMATION OF BREAKDOWN VOLTAGE PARAMETERS}

П I timate the $U_{50}$ value in self-restoring insulations. In this test the voltage is applied at various levels $A_{j}$ selected such that $A_{j+1}=A_{j}+d$, where $d$ is a constant

0018-9367/88/0600-35781.00 (C) 1888 IEEE 
voltage increment. Only one shot at a time is applied at a given level. The voltage level is then changed to $A_{j-1}$ if the application resulted in a breakdown, or to $A_{j+1}$ if the result was a withstand. A test sequence consists of a total of $N$ voltage applications at $I$ different voltage levels. The result of such a sequence can, without loss of relevant information, be summarized in a square matrix $n_{i j}$ with $I$ rows and $I$ columns. Each matrix element $n_{i j}$ indicates the number of times the level has been changed from $\mathrm{i}$ to $\mathrm{j}$. Consequently, all elements which are not of the form $n_{j, j-1}$ or $n_{j, j+1}$, are zero. For $I=5$ the matrix will be of the form

$$
\left(\begin{array}{ccccc}
n_{21} & 0 & n_{23} & 0 & 0 \\
0 & n_{32} & 0 & n_{34} & 0 \\
0 & 0 & n_{43} & 0 & n_{45} \\
0 & 0 & 0 & n_{54} & 0
\end{array}\right)
$$

It is seen that

$$
N=\sum_{j=1}^{I}\left(n_{j, j-1}+n_{j, j+1}\right)
$$

The maximum likelihood estimates of $U_{50}$ and $\sigma$ do not depend on the individual order of the breakdowns and withstands but only on the number of passages of each level as given by the square matrix. Furthermore, the estimate depends on the distribution that has been assumed for the estimation procedure.

Let $P\left(A_{j}, \mu, \sigma\right)$ denote the breakdown probability at level $A_{j}$ in a distribution with $50 \%$ value $\mu=U_{50}$ and scale parameter $\sigma$. The likelihood function corresponding to the observations $n_{i, j}$ is the probability of obtaining the observations, which can be written as

$$
L(\mu, \sigma)=\prod_{j=1}^{I}\left[\left\{1-P\left(A_{j}, \mu, \sigma\right)\right\}^{n_{j, j+1}} P\left(A_{j}, \mu, \sigma\right)^{n_{j, j-1}}\right]
$$

The maximum likelihood estimates of $\mu$ and $\sigma$ are the values of $\mu$ and $\sigma$ maximizing $L(\mu, \sigma)$. In practice it is simpler to maximize $\ln (L)$. Generally no explicit solution exists and hence the maximum has to be determined by numerical methods.

\section{BREAKDOWN PROBABILITY FUNCTIONS}

$\mathrm{T}$

HE various probability distributions considered in 1 the present analysis have all been standardized such that they possess the same $50 \%$ value and the same slope at the $50 \%$ level as the normal distribution. The distributions under consideration are

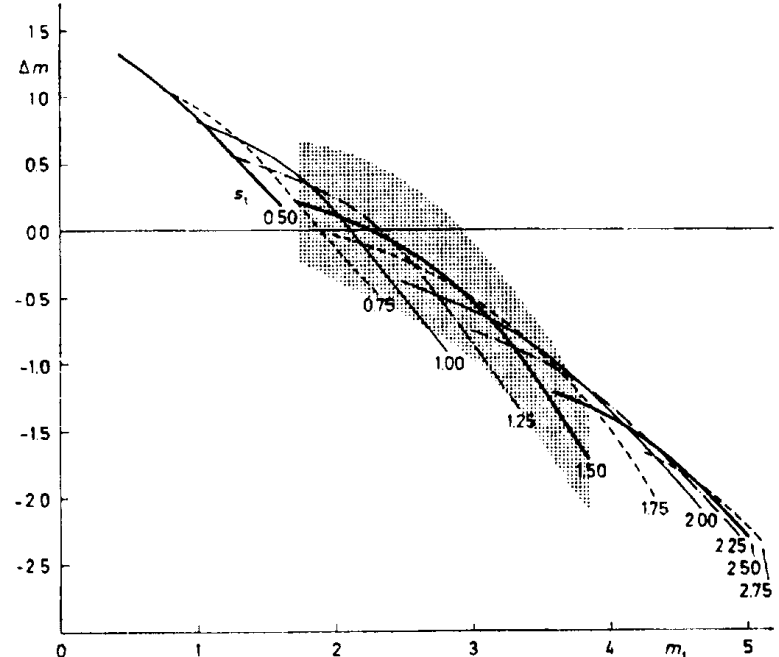

Figure 1.

The average estimation bias $\Delta m=m_{e}-m_{t}$ for the position as function of $m_{t}$ and with $s_{t}$ as parameter. The double exponential distribution is the true and the Weibull-5 distribution the estimated distribution. The hatched area indicates the standard deviation for the results for $s_{t}=1.5$.

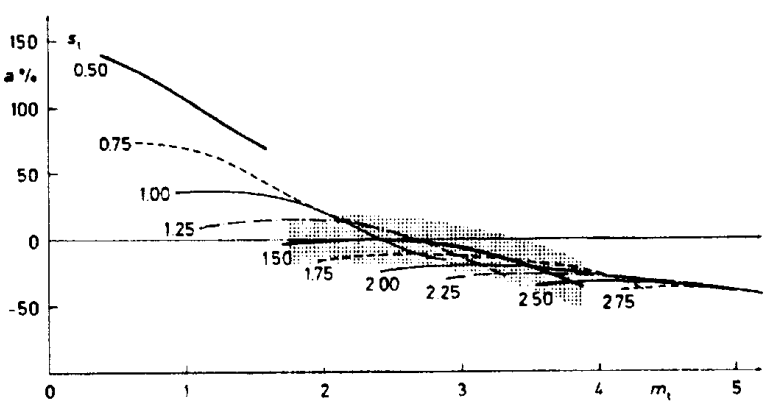

Figure 2.

The relative average estimation bias $a$ for the scale as function of $m_{t}$ and with $s_{t}$ as parameter. The double exponential distribution is the true and the Weibull-5 distribution the estimated distribution. The hatched area indicates the standard deviation for the results for $s_{t}=1.5$.

1. Normal distribution

$$
P(x)=\frac{1}{\sigma \sqrt{2 \pi}} \int_{-\infty}^{x} \exp \left[\frac{-(t-\mu)^{2}}{2 \sigma^{2}}\right] d t
$$


Table 1.

Exact maximum likelihood estimates of $m=\left(U_{50}-A_{1}\right) / d$ and $s=d / \sigma$ for selected responses in an up-and-down test with $N=20$ shots over 4 voltage levels, for four distribution functions.

\begin{tabular}{|c|c|c|c|c|c|c|c|}
\hline \multicolumn{2}{|c|}{$\begin{array}{l}\text { Normal } \\
\text { distribution }\end{array}$} & \multicolumn{2}{|c|}{$\begin{array}{l}\text { Double exp. } \\
\text { distribution }\end{array}$} & \multicolumn{2}{|c|}{$\begin{array}{l}\text { Logistic } \\
\text { distribution }\end{array}$} & \multicolumn{2}{|c|}{$\begin{array}{l}\text { Weibull-5 } \\
\text { distribution }\end{array}$} \\
\hline$\hat{m}$ & $\hat{s}$ & $\hat{m}$ & $\hat{s}$ & $\hat{m}$ & $\hat{s}$ & $\hat{m}$ & $\hat{s}$ \\
\hline $\begin{array}{l}1.47 \\
1.28 \\
1.20\end{array}$ & $\begin{array}{l}1.30 \\
1.29 \\
0.95\end{array}$ & $\begin{array}{l}1.37 \\
1.10 \\
1.16\end{array}$ & $\begin{array}{l}1.12 \\
1.03 \\
0.84\end{array}$ & $\begin{array}{l}1.52 \\
1.34 \\
1.18\end{array}$ & $\begin{array}{l}1.38 \\
1.41 \\
0.95\end{array}$ & $\begin{array}{l}1.44 \\
1.22 \\
1.19\end{array}$ & $\begin{array}{l}1.23 \\
1.18 \\
0.91\end{array}$ \\
\hline $\begin{array}{l}1.70 \\
1.45 \\
1.39\end{array}$ & $\begin{array}{l}1.39 \\
1.32 \\
1.03\end{array}$ & $\begin{array}{l}1.67 \\
1.32 \\
1.40\end{array}$ & $\begin{array}{l}1.27 \\
1.12 \\
0.96\end{array}$ & $\begin{array}{l}1.76 \\
1.50 \\
1.39\end{array}$ & $\begin{array}{l}1.46 \\
1.40 \\
1.03\end{array}$ & $\begin{array}{l}1.69 \\
1.40 \\
1.40\end{array}$ & $\begin{array}{l}1.34 \\
1.24 \\
1.00\end{array}$ \\
\hline $\begin{array}{l}1.15 \\
1.25 \\
2.06\end{array}$ & $\begin{array}{l}0.96 \\
0.84 \\
1.56\end{array}$ & $\begin{array}{l}1.07 \\
1.33 \\
2.12\end{array}$ & $\begin{array}{l}0.84 \\
0.84 \\
1.50\end{array}$ & $\begin{array}{l}1.13 \\
1.23 \\
2.16\end{array}$ & $\begin{array}{l}0.97 \\
0.83 \\
1.64\end{array}$ & $\begin{array}{l}1.13 \\
1.28 \\
2.07\end{array}$ & $\begin{array}{l}0.91 \\
0.84 \\
1.53\end{array}$ \\
\hline $\begin{array}{l}1.70 \\
1.68 \\
1.35\end{array}$ & $\begin{array}{l}1.41 \\
1.16 \\
1.04\end{array}$ & $\begin{array}{l}1.63 \\
1.76 \\
1.33\end{array}$ & $\begin{array}{l}1.27 \\
1.14 \\
0.96\end{array}$ & $\begin{array}{l}1.77 \\
1.71 \\
1.35\end{array}$ & $\begin{array}{l}1.49 \\
1.19 \\
1.06\end{array}$ & $\begin{array}{l}1.67 \\
1.71 \\
1.35\end{array}$ & $\begin{array}{l}1.36 \\
1.15 \\
1.01\end{array}$ \\
\hline $\begin{array}{l}1.51 \\
119 \\
1.44\end{array}$ & $\begin{array}{l}0.96 \\
0.85 \\
0.85\end{array}$ & $\begin{array}{l}1.65 \\
1.22 \\
1.67\end{array}$ & $\begin{array}{l}0.99 \\
0.82 \\
0.93\end{array}$ & $\begin{array}{l}1.52 \\
1.16 \\
1.44\end{array}$ & $\begin{array}{l}0.96 \\
0.84 \\
0.84\end{array}$ & $\begin{array}{l}1.56 \\
1.20 \\
1.51\end{array}$ & $\begin{array}{l}0.97 \\
0.84 \\
0.88\end{array}$ \\
\hline $\begin{array}{l}2.65 \\
2.09 \\
2.16\end{array}$ & $\begin{array}{l}1.87 \\
1.61 \\
1.40\end{array}$ & $\begin{array}{l}2.82 \\
2.10 \\
2.35\end{array}$ & $\begin{array}{l}1.87 \\
1.52 \\
1.45\end{array}$ & $\begin{array}{l}2.79 \\
2.19 \\
2.24\end{array}$ & $\begin{array}{l}1.97 \\
1.70 \\
1.46\end{array}$ & $\begin{array}{l}2.66 \\
2.08 \\
2.20\end{array}$ & $\begin{array}{l}1.84 \\
1.56 \\
1.40\end{array}$ \\
\hline $\begin{array}{l}1.67 \\
1.93 \\
1.46\end{array}$ & $\begin{array}{l}1.19 \\
1.16 \\
0.97\end{array}$ & $\begin{array}{l}1.70 \\
2.15 \\
1.55\end{array}$ & $\begin{array}{l}1.15 \\
1.23 \\
0.97\end{array}$ & $\begin{array}{l}1.70 \\
1.98 \\
1.46\end{array}$ & $\begin{array}{l}1.22 \\
1.19 \\
0.97\end{array}$ & $\begin{array}{l}1.68 \\
2.00 \\
1.50\end{array}$ & $\begin{array}{l}1.17 \\
1.18 \\
0.98\end{array}$ \\
\hline $\begin{array}{l}1.83 \\
1.36 \\
1.82\end{array}$ & $\begin{array}{l}1.03 \\
0.85 \\
0.96\end{array}$ & $\begin{array}{l}2.17 \\
1.53 \\
2.32\end{array}$ & $\begin{array}{l}1.16 \\
0.90 \\
1.17\end{array}$ & $\begin{array}{l}1.89 \\
1.35 \\
1.90\end{array}$ & $\begin{array}{l}1.05 \\
0.84 \\
0.99\end{array}$ & $\begin{array}{l}1.93 \\
1.42 \\
1.96\end{array}$ & $\begin{array}{l}1.07 \\
0.87 \\
1.02\end{array}$ \\
\hline $\begin{array}{l}3.02 \\
2.18 \\
2.69\end{array}$ & $\begin{array}{l}1.86 \\
1.45 \\
1.55\end{array}$ & $\begin{array}{l}3.55 \\
2.33 \\
3.10\end{array}$ & $\begin{array}{l}2.08 \\
1.47 \\
1.71\end{array}$ & $\begin{array}{l}3.23 \\
2.27 \\
2.88\end{array}$ & $\begin{array}{l}1.97 \\
1.51 \\
1.64\end{array}$ & $\begin{array}{l}3.11 \\
2.21 \\
2.78\end{array}$ & $\begin{array}{l}1.88 \\
1.45 \\
1.57\end{array}$ \\
\hline $\begin{array}{l}1.91 \\
2.56\end{array}$ & $\begin{array}{l}1.19 \\
1.38\end{array}$ & $\begin{array}{l}2.06 \\
2.99\end{array}$ & $\begin{array}{l}1.22 \\
1.54\end{array}$ & $\begin{array}{l}1.96 \\
2.75\end{array}$ & $\begin{array}{l}1.22 \\
1.47\end{array}$ & $\begin{array}{l}1.96 \\
2.68\end{array}$ & $\begin{array}{l}1.20 \\
1.42\end{array}$ \\
\hline $\begin{array}{l}1.78 \\
2.57\end{array}$ & $\begin{array}{l}1.04 \\
1.31\end{array}$ & $\begin{array}{l}2.02 \\
3.20\end{array}$ & $\begin{array}{l}1.13 \\
1.55\end{array}$ & $\begin{array}{l}1.82 \\
2.82\end{array}$ & $\begin{array}{l}1.06 \\
1.41\end{array}$ & $\begin{array}{l}1.86 \\
2.73\end{array}$ & $\begin{array}{l}1.07 \\
1.37\end{array}$ \\
\hline
\end{tabular}

2. Double exponential distribution

$$
P(x)=1-\exp \left(-\exp \left(\frac{x-\delta}{\gamma}\right)\right)
$$

standardized with $\delta=\mu-\ln (\ln (2)) \ln (2) \sqrt{\frac{\pi}{2}} \sigma$ and

$$
\gamma=\ln (2) \sqrt{\frac{\pi}{2}} \sigma
$$

3 Logistic distribution

$$
P(x)=\frac{1}{1+\exp \left[-(x-\kappa)^{2} / \zeta\right]}
$$

4. Weibull-5 distribution

$$
\begin{gathered}
P(x)=1-\exp \left[-\left(\frac{x-\delta}{\alpha}\right)^{\beta}\right] \quad \text { for } x>\delta \\
P(x)=0 \quad \text { for } x \leq \delta
\end{gathered}
$$


Table 2.

Exact maximum likelihood estimates of $m=\left(U_{50}-A_{1}\right) / d$ and $s=d / \sigma$ for selected responses in an up-and-down test with $N=20$ shots over 5 voltage levels, for four distribution functions.

\begin{tabular}{|c|c|c|c|c|c|c|c|c|c|c|c|c|c|c|c|}
\hline \multirow[b]{2}{*}{$n_{12}$} & \multirow[b]{2}{*}{$n_{21}$} & \multirow[b]{2}{*}{$n_{23}$} & \multirow[b]{2}{*}{$n_{32}$} & \multirow[b]{2}{*}{$n_{34}$} & \multirow[b]{2}{*}{$n_{43}$} & \multirow[b]{2}{*}{$n_{45}$} & \multirow[b]{2}{*}{$n_{54}$} & \multicolumn{2}{|c|}{$\begin{array}{l}\text { Normal } \\
\text { distribution }\end{array}$} & \multicolumn{2}{|c|}{$\begin{array}{l}\text { Double exp. } \\
\text { distribution }\end{array}$} & \multicolumn{2}{|c|}{$\begin{array}{l}\text { Logistic } \\
\text { distribution }\end{array}$} & \multicolumn{2}{|c|}{$\begin{array}{l}\text { Weibull-5 } \\
\text { distribution }\end{array}$} \\
\hline & & & & & & & & $\hat{m}$ & $\hat{s}$ & $\hat{m}$ & $\hat{s}$ & $\hat{m}$ & $\hat{s}$ & $\hat{m}$ & $\hat{s}$ \\
\hline $\begin{array}{l}4 \\
4 \\
4\end{array}$ & $\begin{array}{l}3 \\
3 \\
4\end{array}$ & $\begin{array}{l}4 \\
3 \\
3\end{array}$ & $\begin{array}{l}3 \\
2 \\
3\end{array}$ & $\begin{array}{l}2 \\
3 \\
2\end{array}$ & $\begin{array}{l}2 \\
3 \\
2\end{array}$ & $\begin{array}{l}1 \\
1 \\
1\end{array}$ & $\begin{array}{l}1 \\
1 \\
1\end{array}$ & $\begin{array}{l}1.17 \\
1.17 \\
0.89\end{array}$ & $\begin{array}{l}0.68 \\
0.64 \\
0.60\end{array}$ & $\begin{array}{l}1.15 \\
1.23 \\
0.83\end{array}$ & $\begin{array}{l}0.62 \\
0.63 \\
0.52\end{array}$ & $\begin{array}{l}1.18 \\
1.17 \\
0.89\end{array}$ & $\begin{array}{l}0.69 \\
0.64 \\
0.61\end{array}$ & $\begin{array}{l}1.17 \\
1.20 \\
0.87\end{array}$ & $\begin{array}{l}0.66 \\
0.64 \\
0.57\end{array}$ \\
\hline $\begin{array}{l}3 \\
3 \\
3\end{array}$ & $\begin{array}{l}2 \\
2 \\
2\end{array}$ & $\begin{array}{l}5 \\
4 \\
4\end{array}$ & $\begin{array}{l}4 \\
3 \\
3\end{array}$ & $\begin{array}{l}2 \\
3 \\
3\end{array}$ & $\begin{array}{l}2 \\
3 \\
2\end{array}$ & $\begin{array}{l}1 \\
1 \\
2\end{array}$ & $\begin{array}{l}1 \\
1 \\
1\end{array}$ & $\begin{array}{l}1.42 \\
1.43 \\
1.22\end{array}$ & $\begin{array}{l}0.79 \\
0.75 \\
0.54\end{array}$ & $\begin{array}{l}1.38 \\
1.50 \\
1.31\end{array}$ & $\begin{array}{l}0.72 \\
0.74 \\
0.56\end{array}$ & $\begin{array}{l}1.46 \\
1.46 \\
1.22\end{array}$ & $\begin{array}{l}0.82 \\
0.76 \\
0.54\end{array}$ & $\begin{array}{l}1.41 \\
1.46 \\
1.25\end{array}$ & $\begin{array}{l}0.76 \\
0.75 \\
0.55\end{array}$ \\
\hline $\begin{array}{l}3 \\
3 \\
3\end{array}$ & $\begin{array}{l}3 \\
2 \\
2\end{array}$ & $\begin{array}{l}4 \\
4 \\
3\end{array}$ & $\begin{array}{l}4 \\
3 \\
2\end{array}$ & $\begin{array}{l}2 \\
2 \\
4\end{array}$ & $\begin{array}{l}2 \\
2 \\
4\end{array}$ & $\begin{array}{l}1 \\
2 \\
1\end{array}$ & $\begin{array}{l}1 \\
2 \\
1\end{array}$ & $\begin{array}{l}1.07 \\
1.24 \\
1.48\end{array}$ & $\begin{array}{l}0.67 \\
0.60 \\
0.73\end{array}$ & $\begin{array}{l}0.99 \\
1.29 \\
1.66\end{array}$ & $\begin{array}{l}0.59 \\
0.60 \\
0.78\end{array}$ & $\begin{array}{l}1.08 \\
1.24 \\
1.52\end{array}$ & $\begin{array}{l}0.69 \\
0.60 \\
0.75\end{array}$ & $\begin{array}{l}1.04 \\
1.26 \\
1.54\end{array}$ & $\begin{array}{l}0.64 \\
0.60 \\
0.75\end{array}$ \\
\hline $\begin{array}{l}3 \\
3 \\
3\end{array}$ & $\begin{array}{l}2 \\
3 \\
2\end{array}$ & $\begin{array}{l}3 \\
3 \\
3\end{array}$ & $\begin{array}{l}2 \\
3 \\
2\end{array}$ & $\begin{array}{l}4 \\
3 \\
3\end{array}$ & $\begin{array}{l}3 \\
3 \\
3\end{array}$ & $\begin{array}{l}2 \\
1 \\
2\end{array}$ & $\begin{array}{l}1 \\
1 \\
2\end{array}$ & $\begin{array}{l}1.29 \\
1.05 \\
1.30\end{array}$ & $\begin{array}{l}0.55 \\
0.62 \\
0.60\end{array}$ & $\begin{array}{l}1.47 \\
1.05 \\
1.45\end{array}$ & $\begin{array}{l}0.61 \\
0.59 \\
0.64\end{array}$ & $\begin{array}{l}1.31 \\
1.05 \\
1.32\end{array}$ & $\begin{array}{l}0.56 \\
0.62 \\
0.61\end{array}$ & $\begin{array}{l}1.35 \\
1.06 \\
1.35\end{array}$ & $\begin{array}{l}0.57 \\
0.61 \\
0.62\end{array}$ \\
\hline $\begin{array}{l}3 \\
2 \\
2\end{array}$ & $\begin{array}{l}2 \\
1 \\
1\end{array}$ & $\begin{array}{l}3 \\
6 \\
5\end{array}$ & $\begin{array}{l}2 \\
5 \\
4\end{array}$ & $\begin{array}{l}3 \\
2 \\
3\end{array}$ & $\begin{array}{l}2 \\
2 \\
3\end{array}$ & $\begin{array}{l}3 \\
1 \\
1\end{array}$ & $\begin{array}{l}2 \\
1 \\
1\end{array}$ & $\begin{array}{l}1.20 \\
1.83 \\
1.86\end{array}$ & $\begin{array}{l}0.48 \\
0.97 \\
0.93\end{array}$ & $\begin{array}{l}1.39 \\
1.69 \\
1.86\end{array}$ & $\begin{array}{l}0.54 \\
0.85 \\
0.89\end{array}$ & $\begin{array}{l}1.21 \\
1.92 \\
1.94\end{array}$ & $\begin{array}{l}0.48 \\
1.04 \\
0.98\end{array}$ & $\begin{array}{l}1.26 \\
1.77 \\
1.86\end{array}$ & $\begin{array}{l}0.50 \\
0.92 \\
0.92\end{array}$ \\
\hline $\begin{array}{l}2 \\
2 \\
2\end{array}$ & $\begin{array}{l}1 \\
1 \\
1\end{array}$ & $\begin{array}{l}5 \\
5 \\
4\end{array}$ & $\begin{array}{l}4 \\
4 \\
3\end{array}$ & $\begin{array}{l}3 \\
2 \\
4\end{array}$ & $\begin{array}{l}2 \\
2 \\
4\end{array}$ & $\begin{array}{l}2 \\
2 \\
1\end{array}$ & $\begin{array}{l}1 \\
2 \\
1\end{array}$ & $\begin{array}{l}1.54 \\
1.55 \\
1.95\end{array}$ & $\begin{array}{l}0.68 \\
0.73 \\
0.93\end{array}$ & $\begin{array}{l}1.61 \\
1.57 \\
2.12\end{array}$ & $\begin{array}{l}0.68 \\
0.70 \\
0.96\end{array}$ & $\begin{array}{l}1.55 \\
1.56 \\
2.05\end{array}$ & $\begin{array}{l}0.69 \\
0.74 \\
0.98\end{array}$ & $\begin{array}{l}1.57 \\
1.56 \\
2.00\end{array}$ & $\begin{array}{l}0.68 \\
0.72 \\
0.94\end{array}$ \\
\hline $\begin{array}{l}2 \\
2 \\
2\end{array}$ & $\begin{array}{l}1 \\
2 \\
1\end{array}$ & $\begin{array}{l}4 \\
4 \\
4\end{array}$ & $\begin{array}{l}3 \\
4 \\
3\end{array}$ & $\begin{array}{l}4 \\
3 \\
3\end{array}$ & $\begin{array}{l}3 \\
3 \\
3\end{array}$ & $\begin{array}{l}2 \\
1 \\
2\end{array}$ & $\begin{array}{l}1 \\
1 \\
2\end{array}$ & $\begin{array}{l}1.66 \\
1.32 \\
1.66\end{array}$ & $\begin{array}{l}0.70 \\
0.73 \\
0.75\end{array}$ & $\begin{array}{l}1.84 \\
1.30 \\
1.79\end{array}$ & $\begin{array}{l}0.75 \\
0.69 \\
0.76\end{array}$ & $\begin{array}{l}1.70 \\
1.34 \\
1.70\end{array}$ & $\begin{array}{l}0.72 \\
0.75 \\
0.76\end{array}$ & $\begin{array}{l}1.72 \\
1.32 \\
1.70\end{array}$ & $\begin{array}{l}0.72 \\
0.72 \\
0.75\end{array}$ \\
\hline $\begin{array}{l}2 \\
2 \\
2\end{array}$ & $\begin{array}{l}1 \\
1 \\
1\end{array}$ & $\begin{array}{l}4 \\
3 \\
3\end{array}$ & $\begin{array}{l}3 \\
2 \\
2\end{array}$ & $\begin{array}{l}3 \\
5 \\
5\end{array}$ & $\begin{array}{l}2 \\
5 \\
4\end{array}$ & $\begin{array}{l}3 \\
1 \\
2\end{array}$ & $\begin{array}{l}2 \\
1 \\
1\end{array}$ & $\begin{array}{l}1.50 \\
2.11 \\
1.83\end{array}$ & $\begin{array}{l}0.60 \\
0.96 \\
0.75\end{array}$ & $\begin{array}{l}1.71 \\
2.50 \\
2.18\end{array}$ & $\begin{array}{l}0.65 \\
1.08 \\
0.87\end{array}$ & $\begin{array}{l}1.52 \\
2.29 \\
1.94\end{array}$ & $\begin{array}{l}0.60 \\
1.03 \\
0.79\end{array}$ & $\begin{array}{l}1.57 \\
2.21 \\
1.93\end{array}$ & $\begin{array}{l}0.62 \\
0.99 \\
0.78\end{array}$ \\
\hline $\begin{array}{l}2 \\
2 \\
2\end{array}$ & $\begin{array}{l}2 \\
1 \\
1\end{array}$ & $\begin{array}{l}3 \\
3 \\
3\end{array}$ & $\begin{array}{l}3 \\
2 \\
2\end{array}$ & $\begin{array}{l}4 \\
4 \\
4\end{array}$ & $\begin{array}{l}4 \\
4 \\
3\end{array}$ & $\begin{array}{l}1 \\
2 \\
3\end{array}$ & $\begin{array}{l}1 \\
2 \\
2\end{array}$ & $\begin{array}{l}1.34 \\
1.82 \\
1.67\end{array}$ & $\begin{array}{l}0.71 \\
0.78 \\
0.64\end{array}$ & $\begin{array}{l}1.43 \\
2.10 \\
2.02\end{array}$ & $\begin{array}{l}0.72 \\
0.86 \\
0.75\end{array}$ & $\begin{array}{l}1.36 \\
1.91 \\
1.74\end{array}$ & $\begin{array}{l}0.72 \\
0.81 \\
0.66\end{array}$ & $\begin{array}{l}1.38 \\
1.90 \\
1.77\end{array}$ & $\begin{array}{l}0.71 \\
0.81 \\
0.68\end{array}$ \\
\hline $\begin{array}{l}2 \\
2 \\
2\end{array}$ & $\begin{array}{l}2 \\
1 \\
1\end{array}$ & $\begin{array}{l}3 \\
3 \\
2\end{array}$ & $\begin{array}{l}3 \\
2 \\
1\end{array}$ & $\begin{array}{l}3 \\
3 \\
4\end{array}$ & $\begin{array}{l}3 \\
3 \\
4\end{array}$ & $\begin{array}{l}2 \\
3 \\
3\end{array}$ & $\begin{array}{l}2 \\
3 \\
3\end{array}$ & $\begin{array}{l}1.14 \\
1.66 \\
1.89\end{array}$ & $\begin{array}{l}0.57 \\
0.68 \\
0.74\end{array}$ & $\begin{array}{l}1.20 \\
1.96 \\
2.39\end{array}$ & $\begin{array}{l}0.57 \\
0.76 \\
0.90\end{array}$ & $\begin{array}{l}1.14 \\
1.71 \\
2.03\end{array}$ & $\begin{array}{l}0.57 \\
0.69 \\
0.79\end{array}$ & $\begin{array}{l}1.16 \\
1.75 \\
2.02\end{array}$ & $\begin{array}{l}0.57 \\
0.70 \\
0.78\end{array}$ \\
\hline
\end{tabular}

$$
\alpha=\beta \sigma \sqrt{\pi / 2}(\ln (2))(\beta-1) / \beta
$$

for a $\beta$ value of 5 .

\section{PROCEDURE}

$T^{N}$ the following analysis the total number of shots $I$ in a test sequence has been set to $N=20$, which makes it practicable to identify the possible array of the matrix $n_{i j}$ associated with a number of test sequences. Furthermore, we shall restrict the analysis to sequences containing 4 or 5 levels, which for $N=20$ ensures that meaningfal information can be obtained. We consider only sequences where the highest voltage level applied has resulted in a breakdown and the lowest level in withstands. All other levels must possess at least one breakdown. The sequence is always started at the lowest level.

All possible sequences with 4 voltage levels and $N=20$ with the above mentioned restrictions lead to 64 different 4th order square matrices representing 9403 different sequences. With 5 levels there are 175 different 5 th order square matrices representing 19105 sequences. Each individual matrix thus contains information from many possible test sequences, for which each sequence has the same probability of occurrence. 


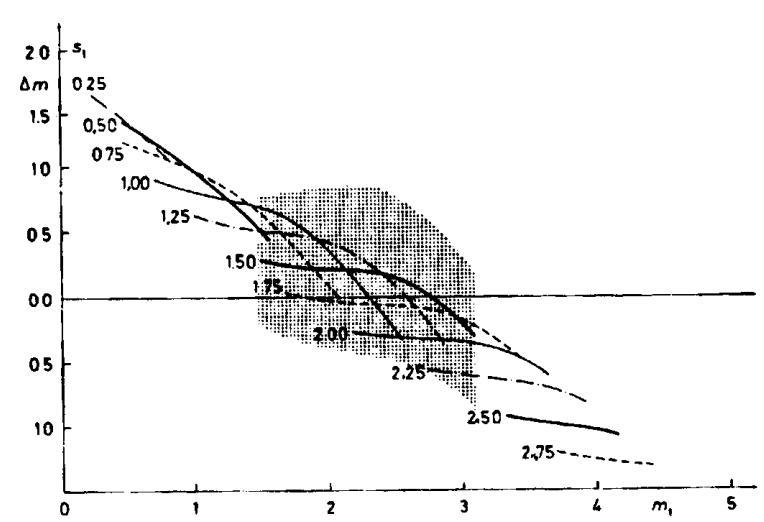

Figure 3.

The average estimation bias $\Delta m=m_{e}-m_{t}$ position as function of $m_{t}$ and with $s_{t}$ as parameter. The Weibull-5 distribution is the true and the the double exponential distribution the estimated distribution. The hatched area indicates the standard deviation for the results for $s_{t}=1.5$.

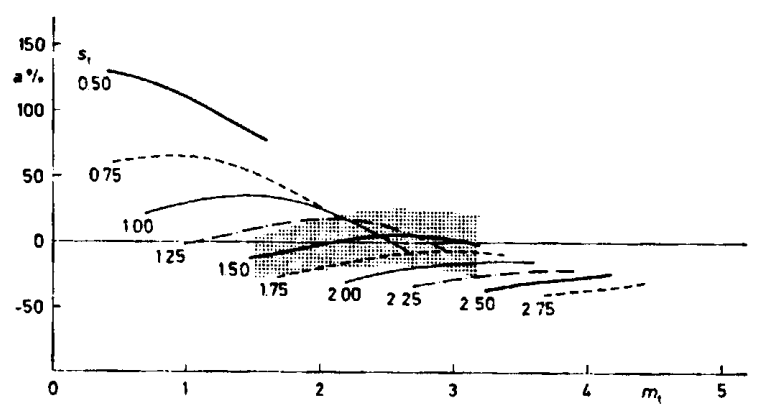

Figure 4.

The relative average estimation bias $a$ for the scale as function of $m_{t}$ and with $s_{t}$ as parameter. The Weibull-5 distribution is the true and the double exponential distribution the estimated distribution. The hatched area indicates the standard deviation for the results for $s_{t}=1.5$.

In order to facilitate the analysis, the following dimensionless quantities $m$ and $s$ are introduced

$$
m=\frac{U_{50}-A_{1}}{d} \quad \text { and } \quad s=\frac{d}{\sigma}
$$

in which $A_{1}$ is the lowest voltage level in the sequence, and $d$ the step size.
Tables 1 and 2 show for selected matrices $n_{i, j}$ the exact values of the maximum likelihood estimates $m$ and $s$, for $N=20$ for a normal distribution of breakdown probabilities, for a double-exponential distribution of breakdown probabilities, a logistic distribution of breakdown probabilities and a Weibull-5 distribution of breakdown probabilities.

The data in Table 1 are limited to those 4th order square matrices which each represent not less than 100 individual sequences, and Table 2 is limited to those 5 th order square matrices each of which contain more than 200 individual sequences. The limitation of the number of selected matrices has made the analysis as comprehensible as possible without losing significant information.

\section{ANALYSIS}

TE probability of obtaining a specific matrix de1 pends on the true distribution, the true values of $U_{50}$ and $\sigma$ and on the values of $A_{1}$ and $d$. When a specific distribution has been chosen for the estimation (not necessarily the true distribution) then the above probability is also the probability of obtaining a specific set of values $(\hat{m}, \hat{s})$ as a maximum likelihood estimate. For a specific set of matrices this probability, and the corresponding set of numbers of different sequences which will lead to each specific matrix in the set, can be utilized to weight the maximum likelihood estimates $(\hat{m}, \hat{s})$ corresponding to the individual matrices. This weighted average of the various possible values of the maximum likelihood estimates will be denoted $\left(m_{e}, s_{c}\right)$ For fixed values of $N, A_{l}$ and $d$ the sum of all the probabilities for all possible matrices, including the ones that have been omitted, will be unity.

In addition to the limitations already imposed on the sets of data under consideration we shall in the following analysis restrict ourselves to consider only such combinations of the true parameters $m$ and $s$ which associate a total probability larger than $5 \%$ with the sets of matrices under investigation. Each set $m_{t} s_{t}$ of the true values of $m$ and $s$ specify probabilities of occurrence for the individual matrices and for the corresponding values of the maximum likelihood estimates. The weighted averages of $m_{e}$ and $s_{e}$ of the maximum likelihood estimates thus depend on the true values $m_{t}$ and $s_{t}$.

Even when the distribution assumed in the estimation is the same as the true distribution there will usually be an estimation bias, with a magnitude depending on the true values of the parameters [5]. In general, $m_{e}$ 
and $s_{e}$ will differ from $m_{t}$ and $s_{t}$. This deviation can be described by the parameters

$$
\Delta m=m_{e}-m_{t}
$$

for the position and

$$
a \equiv \frac{s_{e}-s_{t}}{s_{t}}
$$

for the scale.

For a given combination of the estimated and true distributions, the average estimation bias $\Delta m$ and $a$ will be functions of $m_{t}$ and $s_{t}$. These functions are for $N=20$ illustrated in Figures 1 to 8 with $m_{t}$ as abscissa and $s_{t}$ as parameter for various sets of estimated and true distributions. The hatched areas in Figures 1 to 8 indicate the standard deviation for the results for $s_{t}=1.5$. In this analysis the normal distribution has not been shown because results based on this distribution are very similar to those obtained from the logistic distribution and the Weibull-5 distribution.

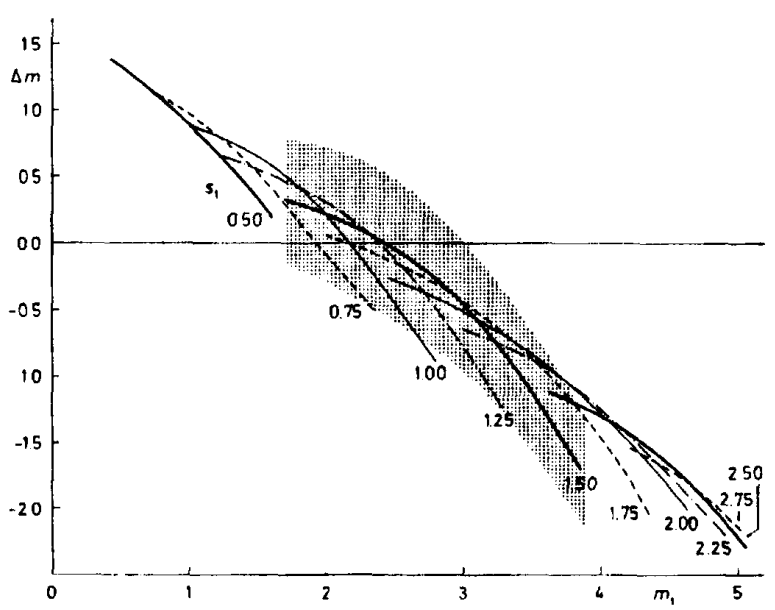

Figure 5.

The average estimation bias $\Delta m=m_{e}-m_{t}$ position as function of $m_{t}$ and with $s_{t}$ as parameter. The double exponential distribution is the true and the logistic distribution the estimated distribution. The hatched area indicates the standard deviation for the results for $s_{t}=1.5$.

Figures 1 to 8 show that both the starting point and the step size are critical for obtaining a small error in the estimated $U_{50}$ and $\sigma$. For $N=20$ the best step size is $d=1.5 \sigma$ and the starting point a little more than two steps below $U_{50}$.

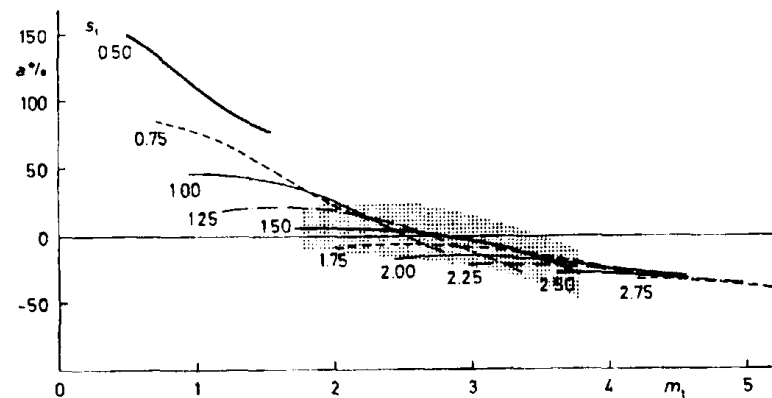

Figure 6.

The relative average estimation bias $a$ for the scale as function of $m_{t}$ and with $s_{t}$ as parameter. The double exponential distribution is the true and the logistic distribution the estimated distribution. The hatched area indicates the standard deviation for the results for $s_{t}=1.5$.

As stated above, the normal, the Weibull-5 and the logistic distributions lead to similar results. The Weibull-5 has zero probability below a certain level $(A<$ $U_{50}-4.34 \sigma$ ) giving the impression of a safe lower limit. Although such a limit is conceivable it has never been verified in practice. The normal and the logistic distributions do not give a finite high or low limit and follow each other rather closely. The logistic distribution is far the easiest to handle mathematically and can replace the normal distribution in any analysis in the field of insulation tests. Experimental results for impulse voltage breakdown characteristics for rod-rod gaps in atmospheric air $[10,11]$ show that the distribution function in the probability range from $1 \%$ to $99 \%$ is represented by a traditional normal distribution, but it might just as well be represented by a logistic distribution, more fitted for computer analysis.

\section{DISCUSSION}

T F the step size $d$ is greater than $1.5 \sigma$, then the esti1 mated scale parameters $s_{e}$ are estimated with increasing bias from the true scale parameter $s_{t}$ in the following order: the double exponential, the logistic, the Weibull5 , and normal distributions. It is surprising that the Weibull-5 distribution gives a better performance than the normal distribution, but the difference is marginal and probably connected with the special choice of patterns and the limited number of shots $N=20$. There is no great difference between the estimation bias for the double exponential, the logistic, the normal, or the 


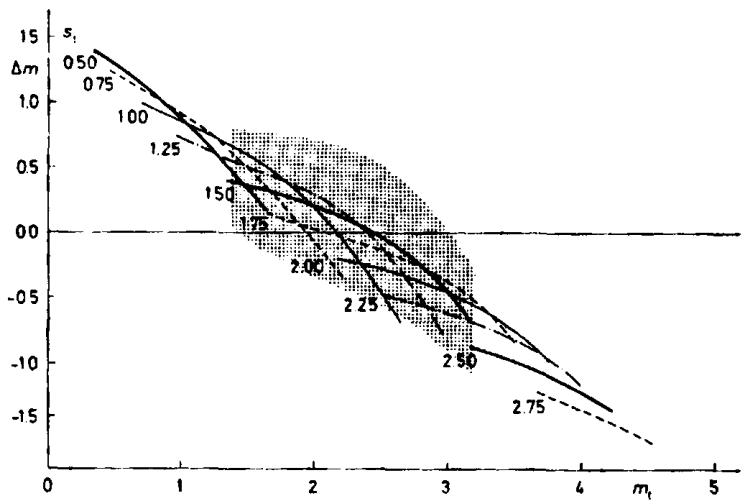

Figure 7 .

The average estimation bias $\Delta m=m_{e}-m_{t}$ for the position as function of $m_{t}$ and with $s_{t}$ as parameter. The Weibull-5 distribution is the true and the logistic distribution the estimated distribution. The hatched area indicates the standard deviation for the results for $s_{t}=1.5$.

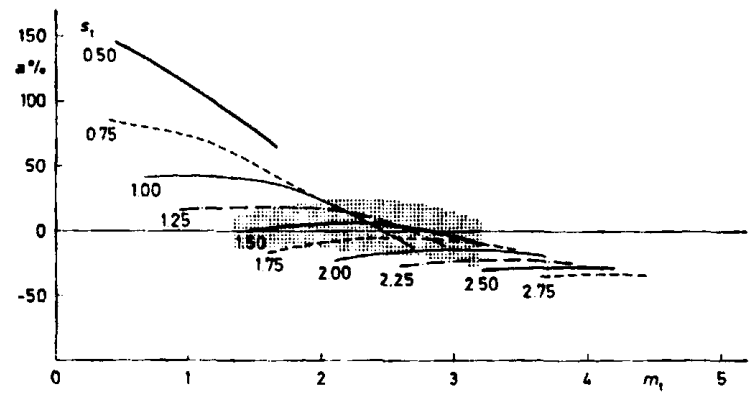

Figure 8.

The relative average estimation bias $a$ for the scale as function of $m_{t}$ and with $s_{t}$ as parameter. The Weibull-5 distribution is the true and the logistic distribution the estimated distribution. The hatched area indicates the standard deviation for the results for $s_{t}=1.5$.

Weibull-5 distributions, independent of the combinations of true and estimated distributions within these four distributions.

\section{CONCLUSIONS}

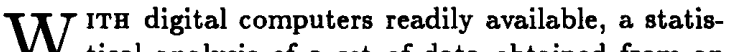
tical analysis of a set of data obtained from an up-and-down test can be obtained directly from a maximum likelihood estimation. This analysis can be simplified by the use of a logistic distribution function without loss of accuracy. In order to determine the optimal values of sample size $N$, start level and step size which would yield the most reliable values of $U_{50}$ it becomes necessary to apply more involved methods than those referred to in the present study.

\section{REFERENCES}

[1] G. Carrara and S. Yakov, "Statistical Evaluation of Dielectric Test Methods", L'Energia Elettrica No. 1, pp. 12-19, '1983.

[2] R. E. Little, "The Up-and-Down Method for Small Samples with Extreme Value Response Distributions", J. Amer. Stat. Assn., Vol. 69, pp. 803-806, 1974.

[3] G. B. Wetherill, "Sequential Estimation of Quantal Response Curves", J. Roy. Stat. Soc., Ser. B, Vol. 25, No. 1, pp. 1-48, 1963.

[4] N. Hylten-Cavallius and F. A. Chagus, "Possible Precision of Statistical Insulation Test Methods", IEEE Trans. PAS, Vol. 102, No. 8, pp. 2372-2378, 1983.

[5] S. Vibholm and P. Thyregod, "The Analysis of Insulation Breakdown Probabilities by the Up-andDown Method", IEEE Trans., Vol. EI-21, no. 2, pp. 133-136, 1986.

[6] A. W. F. Edwards, Likelihood, Cambridge U. P., London 1976

[7] G. W. Brown, "Method of Maximum Likelihood Applied to the Analysis of Flashover Data", IEEE Trans. PAS, Vol. 88, No. 12, pp. 1823-1830, 1969.

[8] W. J. Dixon, "The Up-and-Down Method for Small Samples", J. Amer. Stat. Assn., Vol. 60, pp. 967978, 1965.

[9] W. J. Dixon and A. M. Mood, "A Method for Obtaining and Analysing Sensitivity Data", J. Amer. Stat. Assn., Vol. 43, pp. 109-126, 1948.

[10] S. Vibholm and A. Pedersen, "On the Reproducibility of Negative Lightning Impulse Breakdown Voltage Distribution for a Rod-Rod Gap", 11th International Conference on Phenomena in Ionized Gases, 
p. 190, Czechoslovak Academy of Science, Prague 1973.

[11] S. Vibholm and A. Pedersen, "Some Factors Affecting the Lightning Impulse Breakdown Voltage Distribution for a Rod-Rod Gap in Air at Atmospheric Pressure", 3rd International Conference on Gas Discharges, IEE Conference Publication No. 118, pp. 434-437, London 1974.

Manuscript was received on 16 Dec 1986, in revised form 25 Mar 1987. 